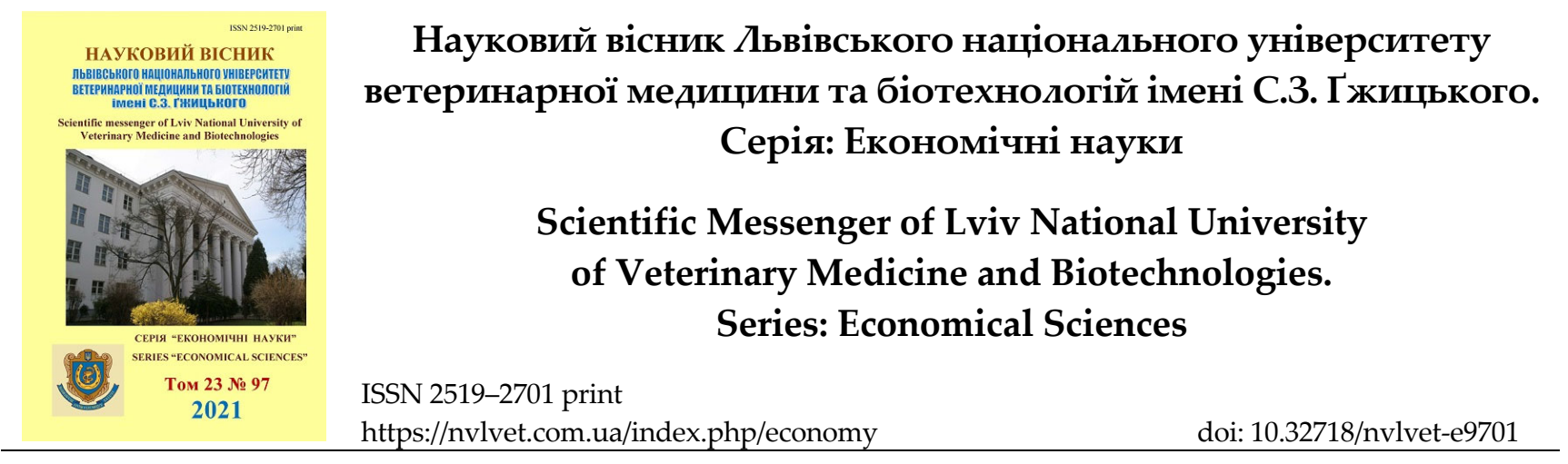

UDC $338.46(477.83)$

\title{
The market of agricultural production services in Ukraine
}

H. Vyslobodska

Stepan Gzhytskyi National University of Veterinary Medicine and Biotechnologies Lviv, Lviv, Ukraine

Article info

Received 06.09.2021

Received in revised form 06.10 .2021

Accepted 07.10.2021

Stepan Gzhytskyi National University of Veterinary Medicine and Biotechnologies Lviv,

Pekarska Str., 50, Lviv, 79010,

Ukraine. Tel.:+38-096-741-15-17

E-mail:vyslgal@i.ua
Vyslobodska, H. (2021). The market of agricultural production services in Ukraine. Scientific Messenger of Lviv National University of Veterinary Medicine and Biotechnologies. Series: Economical Sciences, 23(97), 3-7. doi: 10.32718/nvlvet-e9701

The article defines the role of the market of agricultural production services in the process of agricultural production. The works of domestic scientists devoted to the efficiency of agricultural production, services sphere and the market of agricultural production services are analyzed. A number of methods have been selected for this study. The essence of the concepts of production service and the market of agricultural production services is defined. There are established that the volume of use of production services in the agricultural production process depends on the area under crops in crop production and the number of heads in animal husbandry. The dynamics of changes in sown areas and livestock in Ukraine are analyzed. It is determined that all production operations in agriculture are carried out in accordance with the technological maps. The definition of the concept of "technological map" is given. Information on the composition of agricultural production services in the field of crop production is given. It is established that agricultural production services in crop production can be carried out both manually and mechanized. The importance of technical equipment of the agricultural enterprise for the implementation of the production process was showed. The presence of the main types of agricultural machinery in agricultural enterprises of Ukraine and households is analyzed. The peculiarities inherent only in production services in the field of agriculture are highlighted. The dependence of the volumes of production services on the total volumes of sown areas in crop production and animals in animal husbandry were shown. The concept of production outsourcing is defined and its place in the activity of agricultural producers is defined. The results of a sociological survey of consumers of agricultural production services are shown and analyzed.

Key words: services, production services, services market, agricultural enterprise, development trends.

\section{Ринок виробничих сільськогосподарських послуг в Україні}

\section{Г. Вислободська}

Львівський національний університет ветеринарної медицини та біотехнологій імені С. 3. Гжицького, м. Львів, Україна

У статті дано визначення ролі ринку виробничих сільськогосподарських послуг у процесі виробництва сільськогосподарської продукиї. Проаналізовано прачі вітчизняних науковців присвячені ефективності сільськогосподарського виробництва, сфери послуг та ринку виробничих сільськогосподарських послуг. Вибрано ряд методів для даного дослідження. Визначено сутність понять виробничі послуги та ринок виробничих сільськогосподарських послуг. Встановлено, щяо обсяги використання виробничих послуг у сільськогосподарському виробничому прочесі залежать від площ вирощування культур у рослинництві та кількості голів у тваринництві. Проаналізовано динаміку зміни посівних площ та поголів'я тварин в Україні. Визначено, шчо всіх виробничі операції y сільському господарстві здійснюються відповідно до технологічних карт. Подано визначення поняття “технологічна карта". Наведено інформацію про склад виробничих сільськогосподарських послуг у галузі рослиннищтва. Встановлено, щчо виробничі сільськогосподарські послуги у рослинництві можуть здійснюватися як вручну, так $і$ механізованим способом. Виявлено важливість технічної забезпеченості сільськогосподарського підприємства для здійснення виробничого процесу. Проаналізовано наявність основних видів сільськогосподарської техніки у сільськогосподарських підприємствах України та господарствах населення. Виділено особливості притаманні лише виробничим послугам в галузі сільського господарства. Показана залежність обсягів залучення виробничих послуг від загальних обсягів посівних площ в рослинництві та поголів'я в галузі тваринництва. Визначено поняття 
виробничого аутсорсингу та визначено його місие в діяльності сільськогосподарських товаровиробників. Показано та проаналізовано результати сочіологічного опитування споживачів виробничих сільськогосподарських послуг.

Ключові слова: послуга, виробничі послуги, ринок послуг, сільськогосподарське підприємство, тенденції розвитку

\section{Вступ}

Актуальність теми. Останніми роками ми спостерігаємо зростання, а подекуди й переважання, частки сфери послуг у передових економіках світу. I хоча Україна й відноситься до країн, які розвиваються, проте ці тенденції так само є для неї притаманними. Сільське господарство є однією з найважливіших галузей економіки, оскільки саме у результаті сільськогосподарського виробництва ринок наповнюється продуктами харчування, що є життєво необхідними для існування людства. Тому сільськогосподарське виробництво здійснюється незважаючи на карантинні обмеження та непередбачувані ситуації в державі. Аграрний сектор економіки також виробляє сировину для подальшої їі переробки на промислових підприємствах. Процес виробництва продукції сільського господарства не може обійтися без залучення виробничих послуг. Таким чином, дослідження стану розвитку ринку виробничих сільськогосподарських послуг в Україні, факторів впливу та динаміки його розвитку є актуальними питаннями сьогодення та потребують проведення подальших більш грунтовних досліджень.

Проблематиці ефективності сільськогосподарського виробництва присвячено багато наукових праць вітчизняних вчених, зокрема наукові доробки В. Голяна (Holian, 2020), М. Денисенка (Denysenko, 2019), Г. Черевка (Cherevko, 2019), І. Севідової (Sievidova \& Leshchenko, 2020), С. Самайчук (Samaichuk, 2020) та інших. В основному публікації науковців-економістів описують специфіку сільськогосподарського виробництва, ефективність вирощування окремих сортів рослин та розведення різних видів тварин. Проте в цих дослідженнях упущено ряд важливих аспектів, зокрема розвитку ринку виробничих сільськогосподарських послуг. Слід зазначити, що дослідження сфери послуг як складової економіки $\epsilon$ досить популярними серед науковців, проте стосуються, або ринку послуг в цілому - праці К. Пугачевської (Puhachevska, 2016), Н. Федоронько (Fedoronko \& Kovalchuk, 2017), або окремих секторів сфери послуг - Н. Мосієва (Moisieieva \& Didenko, 2019), Т. Федоренко (Fedorenko, 2020) та ін. Тематиці ринку виробничих сільськогосподарських послуг не приділяється достатньо уваги. $Є$ невелика кількість праць присвячених даній тематиці, зокрема наукові доробки O. Ульянченка (Ulianchenko \& Prozorova, 2016), В. Петрова (Petrov, 2020). Але враховуючи значення виробничих послуг у виробництві аграрної продукції, дослідження ринку виробничих сільськогосподарських послуг $\epsilon$ актуальними.

Мета $і$ завдання дослідження полягає у здійсненні аналізу стану ринку виробничих сільськогосподарсь- ких послуг в Україні, виявленні тенденцій його подальшого розвитку.

\section{Матеріал і методи досліджень}

У дослідженні стану ринку виробничих сільськогосподарських послуг України використовувалися загальнонаукові методи дослідження, зокрема: монографічний метод, при комплексному дослідженні проблем розвитку ринку виробничих послуг, аналіз та синтез, при порівнянні обсягів посівних площ, поголів'я тварин, складу машинно-тракторного парку України, відображенні результатів анкетного опитування покупців виробничих сільськогосподарських послуг; графічний - при відображенні наявності сільськогосподарської техніки у сільськогосподарських підприємствах та господарствах населення.

\section{Результати та їх обговорення}

Аграрна сфера є однією з найважливіших частин економіки України. Виготовляючи сільськогосподарську продукцію виробники споживають виробничі послуги, без яких виробничий процес у АПК $є$ неможливим. Ринком виробничих сільськогосподарських послуг вважається сукупність виробників та надавачів виробничих послуг, інфраструктурних підрозділів, що взаємодіють на певній території з приводу купівлі чи продажу послуг.

Виробничі послуги у сільському господарстві $\epsilon$ особливим видом послуг, для виробничого процесу в аграрному секторі вони відіграють таку ж роль як і оборотні матеріали (насіння, добрива і т.п.), оскільки без сівби чи комбайнування неможливо отримати кінцевий результат - готову сільськогосподарську продукцію (Vyslobodska, 2016).

Обсяги використання виробничих послуг у сільськогосподарському виробничому процесі залежать від площ вирощування культур у рослинництві та кількості голів у тваринництві. Відповідно до цього, проведемо аналіз динаміки зміни цих показників в Україні протягом останніх років (табл. 1).

Дані таблиці 1 свідчать про скорочення обсягів здійснення більшості видів сільськогосподарської діяльності - вирощування цукрових буряків, соняшнику, картоплі, розведення усіх видів тварин; зростання спостерігається лише в обсягах виробництва зернових (на 6,4 \%) та овочів (на 1,1 \%). Незважаючи на зменшення обсягів виробництва сільськогосподарської продукції протягом останніх років, потреби у використанні виробничих сільськогосподарських послуг в Україні залишаються на високому рівні. 
Таблиця 1

Посівні площі сільськогосподарських культур та поголів’я в Україні, тис. га / тис. голів*

\begin{tabular}{lccccc}
\hline \multicolumn{1}{c}{ Культура / Вид тварин } & \multicolumn{3}{c}{ Роки } & \multicolumn{2}{c}{2019 р. до } \\
\cline { 2 - 5 } & 2016 p., \% \\
\hline Зернові та зернобобові & 14401,0 & 14624,0 & 14839,0 & 15318,0 & 106,4 \\
Цукрові буряки & 292,0 & 316,0 & 276,0 & 222,0 & 76,0 \\
Соняшник & 6073,0 & 6034,0 & 6117,0 & 5928,0 & 97,6 \\
Картопля & 1312,0 & 1323,0 & 1319,0 & 1309,0 & 99,8 \\
Овочі & 447,0 & 445,0 & 439,0 & 452,0 & 101,1 \\
ВРХ & 3750,3 & 3682,3 & 3530,8 & 3332,9 & 88,9 \\
Свині & 7079,0 & 6669,1 & 6109,9 & 6025,3 & 85,1 \\
Вівці та кози & 1325,3 & 1314,8 & 1309,3 & 1268,6 & 95,7 \\
\hline
\end{tabular}

*Джерело: сформовано автором на основі даних (Derzhavna Sluzhba Statystyky Ukrainy, 2020)

Усі процеси виробництва агропродукції здійснюється згідно із технологічними картами вирощування культур та тварин. Технологічна карта - це внутрішньогосподарський документ, де проводяться розрахунки планових технологічних операцій, що застосовуються в процесі вирощування культур чи групи тварин; у ньому вказуються обсяги операцій, часові рам- ки та порядок їх виконання. Ці документи описують розрахунки технічних та економічних показників за кожною здійснюваною операцією (витрати палива, затрати праці, кількість умовних еталонних гектарів і т.п.) (Ruzhytskyi et al., 2010). В більшій мірі операції із застосуванням виробничих сільськогосподарських послуг стосуються рослинництва (табл. 2).

\section{Таблиця 2}

Виробничі послуги в рослинництві*

\begin{tabular}{ll}
\hline \multicolumn{1}{c}{ Група послуг } & \multicolumn{1}{c}{ Виробничі послуги, що включаються в групу } \\
\hline & 1. Оранка \\
I. Основний обробіток грунту & 2. Дискування \\
& 3. Лущення стерні \\
& 4. Чизелювання \\
& 5. Плоскорізний обробіток \\
\hline & 1. Боронування; \\
& 2. Протруювання насіння; \\
II. Передпосівний обробіток грунту та сівба (садіння) & 3. Культивація; \\
& 4. Навантаження та доставка добрив; \\
& 5. Сівба (садіння); \\
& 6. Коткування посівів. \\
\hline & 1. Застосування гербіцидів та пестицидів; \\
III. Догляд за посівами & 2. Міжрядного обробітку грунту; \\
& 3. Меліорації та осушення земель тощо. \\
& 1. Комбайнування; \\
IV. Збирання урожаю та підготовка продукції до & 2. Викопування картоплі; \\
первинної реалізації & 3. Збір інших культур; \\
& 4. Транспортування продукції з поля; \\
& 5. Сушіння зерна; \\
& 6. Збір та обробка побічної продукції (соломи, гички тощо). \\
\hline
\end{tabular}

*Джерело: власна розробка автора

Виробничі сільськогосподарські послуги у рослинництві можуть здійснюватися як вручну, так i механізованим способом. Саме тому важливе значення має саме технічна забезпеченість сільськогосподарського підприємства. Динаміку зміни наявності сільськогосподарської техніки у сільськогосподарських підприємствах України та господарствах населення відобразимо у табл. 3.

Дані таблиці 3 свідчать про істотне зменшення кількості сільськогосподарської техніки в Україні. Це можна пояснити зношенням старої сільськогосподарської техніки, в тому числі й моральне, впровадженням більш продуктивних новітніх технологій у виробничий процес. Окрім сільськогосподарських підприємств аграрну продукцію виробляю також і господарства населення. Вони також можуть споживати та надавати виробничі сільськогосподарські послуги, частина $з$ них володіє сільськогосподарською технікою. 
Таблиця 3

Наявність окремих видів сільськогосподарської техніки (на кінець року, шт.)*

\begin{tabular}{lccc}
\hline & Показник & 2018 рік & 2019 рік \\
\hline Трактори & 377306 & 310607 & 82,3 \\
Комбайни & 42925 & 41110 & 95,8 \\
Сівалки & 195922 & 189013 & 96,5 \\
Плуги & 351830 & 310249 & 88,2 \\
Культиватори & 210156 & 192660 & 91,7 \\
Борони & 524819 & 502567 & 95,8 \\
\hline
\end{tabular}

*Джерело: сформовано автором на основі даних (Derzhavna Sluzhba Statystyky Ukrainy, 2020)

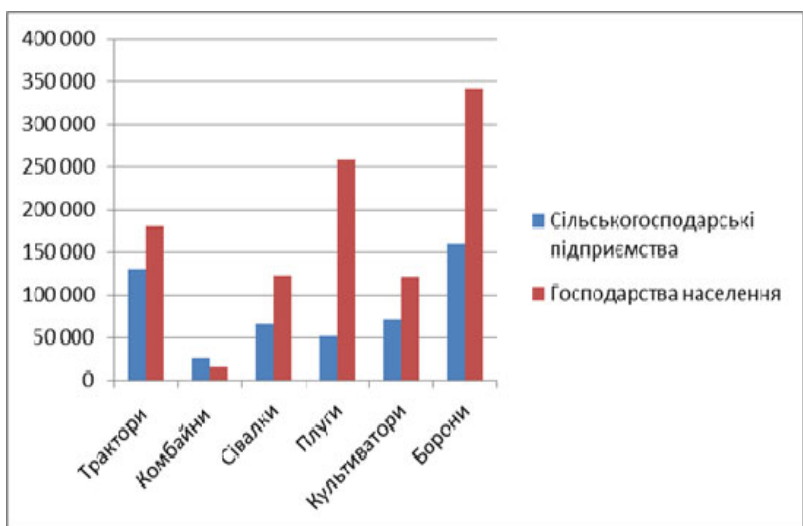

Рис. 1. Наявність сільськогосподарської техніки у сільськогосподарських підприємствах та господарствах населення*

Джерело: сформовано автором на основі даних (Derzhavna Sluzhba Statystyky Ukrainy, 2020)
Здійснення сільськогосподарського виробництва характеризується застосуванням великої кількості різних технологій та комплексів машин, придбання та обслуговування яких потребує залучення значних фінансових ресурсів. Відсутність власних коштів та недосконалість фінансово-кредитного механізму в країні не дозволяє сільськогосподарським виробникам забезпечувати свої потреби у виробничих послугах, змушує шукати можливості їх покриття. Щоб вирішити цю проблему суб' єкти аграрного ринку залучають (купують) виробничі послуги зі сторони. Таке явище має назву “виробничий аутсорсинг”.

Оскільки статистичної інформації про споживання виробничих послуг зі сторони практично немає, то для розуміння фактичного стану ринку виробничих сільськогосподарських послуг було проведено соціологічне дослідження. Відповіді респондентів - покупців виробничих послуг відображено у таблиці 4.

\section{Таблиця 4}

Споживання виробничих сільськогосподарських послуг респондентами* зі сторони**

\begin{tabular}{lccc}
\hline \multicolumn{1}{c}{ Послуга } & \multicolumn{3}{c}{ Структура відповідей, \% } \\
\cline { 2 - 4 } Оранка & Постійно & Інколи & Не костуюся \\
Культивація & 97 & 0 & 3 \\
Дискування & 94 & 0 & 6 \\
Міжрядний обробіток грунту & 95 & 0 & 5 \\
Механізований посів зернових & 41 & 8 & 51 \\
Садіння картоплі & 54 & 30 & 16 \\
Комбайнове збирання зернових & 36 & 28 & 36 \\
Скошування трав & 100 & 0 & 0 \\
Механізоване копання картоплі & 39 & 21 & 40 \\
Обприскування & 95 & 0 & 5 \\
Внесення органічних добрив & 46 & 7 & 49 \\
Внесення мінеральних добрив & 29 & 27 & 44 \\
Транспортні послуги & 24 & 29 & 47 \\
Послуги робочою худобою (коні) & 45 & 30 & 25 \\
Ветеринарні послуги & 12 & 16 & 0 \\
\hline
\end{tabular}

*До числа респондентів ввійшли сільськогосподарські підприємства, кооперативи, фізичні особи-підприємці та домогосподарства Буського, Бродівського та Золочівського районів Львівської області;

**Джерело: розраховано автором на основі опрацьованої анкети споживачів виробничих сільськогосподарських послуг

Як бачимо, є виробничі послуги, які сільгоспвиробники часто купують зі сторони, сюди відносяться комбайнове збирання зернових (100\% опитаних), оранка (97 \%), дискування (95 \%), культивація (94 \%), механізоване збирання картоплі (95\%), ветеринарні послуги (100 \%) та послуги, які залучаються зі сторони рідко, зокрема послуги робочою худобою, внесення добрив тощо.
Ринок виробничих сільськогосподарських послуг має певні особливості: вони є одним із основних та незамінних компонентів виробничого процесу; діяльність 3 надання виробничих послуг може стати ще одним джерелом отримання доходів сільськогосподарськими товаровиробниками; процес надання виробничих сільськогосподарських послуг тісно пов'язаний до об'єктів на яких здійснюється виробництво (земля, поголів'я); споживання того чи іншого 
виду виробничої сільськогосподарської послуги залежить від спеціалізації господарства.

\section{Висновки}

Виробництво сільськогосподарської продукції включає в себе використання виробничих послуг. Ринок цього специфічного “товару” має свої непритаманні іншим ринкам особливості, зокрема прив'язаність процесу надання-споживання до території та необхідність застосовувати виробничі послуги лише в чітко визначеній послідовності. На ринку виробничих сільськогосподарських послуг України у 2016-2019 рр. спостерігається скорочення обсягів їх надання, проте це не свідчить про скорочення обсягів готової сільськогосподарської продукції.

Перспективи подальших досліджень. Важливим напрямом досліджень ринку виробничих сільськогосподарських послуг України, на наш погляд, повинен стати моніторинг локальних ринків, що дозволить отримати більше інформації про дану діяльність в Україні, провести іiі детальний аналіз та сформувати конкретні рекомендації для вдосконалення діяльності суб'єктів на даному ринку.

\section{References}

Cherevko, H. V. (2019). Derzhavne rehuliuvannia diialnosti ahrokholdynhiv $\mathrm{v}$ umovakh konkurentsii v silskomu hospodarstvi. Ahrarna ekonomika, 12(1-2), 8-16. doi: 10.31734/agrarecon2019.01.008 (in Ukrainian).

Denysenko, M. P., \& Novikov, D. V. (2019). Suchasnyi stan ta perspektyvy rozvytku silskoho hospodarstva Ukrainy. Ahrosvit, 12, 15-21. doi: 10.32702/23066792.2019.12.15 (in Ukrainian).

Derzhavna Sluzhba Statystyky Ukrainy. URL: http://www.ukrstat.gov.ua (in Ukrainian).

Fedorenko, T. M. (2020). Doslidzhennia konkurentnoho seredovyshcha subiektiv rynku turystychnykh posluh Ukrainy $\mathrm{v}$ konteksti formuvannia stratehii staloho rozvytku. Investytsii: praktyka ta dosvid, 2, 68-75. doi: 10.32702/2306-6814.2020.2.68 (in Ukrainian).

Fedoronko, N. I. \& Kovalchuk, N. O. (2017). Osoblyvosti suchasnoho stanovyshcha rynku posluh Ukrainy. Molodyi vchenyi, 3(43), 871-874. URL: http://molodyvcheny.in.ua/files/journal/2017/3/199.pd $\mathrm{f}$ (in Ukrainian).
Holian, V. A., \& Zastavnyi, Yu. B. (2020). Finansovoekonomichne rehuliuvannia silskohospodarskoho vyrobnytstva: priorytety ta instrumenty. Ahrosvit, 3, 2026. doi: 10.32702/2306-6792.2020.3.20 (in Ukrainian).

Moisieieva, N. I., \& Didenko, D. F. (2019). Rynok turystychnykh posluh rehionu: sutnist, teoretychni osnovy sehmentatsii, dyferentsiatsii. Visnyk KhNAU im. V.V. Dokuchaieva. Seriia "Ekonomichni nauky", 1, 131-145. doi: 10.31359/2312-3427-2019-1-131 (in Ukrainian).

Petrov, V. M. (2020). Rynok vyrobnykh posluh u silskomu hospodarstvi Ukrainy. Pidpryiemnytstvo v ahrarnii sferi: hlobalni vyklyky ta efektyvnyi menedzhment : materialy I Mizhnar. nauk.-prakt. konf. Ch. I, 12-13 liutoho 2020 r. Zaporizhzhia, 217-220 (in Ukrainian).

Puhachevska, K. I. (2016). Sfera posluh v Ukraini: Osoblyvosti rozvytku ta stratehichni perspektyvy. Naukovyi visnyk Mizhnarodnoho humanitarnoho universytetu. Seriia: Ekonomika i menedzhment, 18, 52-55. URL: http://nbuv.gov.ua/UJRN/Nvmgu_eim_2016_18_12 (in Ukrainian).

Ruzhytskyi, M. A., Riabets, V. I., Kiiashko, V. M. ta in. (2010). Ekspluatatsiia mashyn i obladnannia: Navchalnyi posibnyk. Kyiv: Ahrarna osvita (in Ukrainian).

Samaichuk, S. I. (2020). Analiz vyrobnytstva silskohospodarskoi produktsii: rehionalnyi aspekt. Ahrosvit, 7, 3136. doi:10.32702/2306-6792.2020.7.31 (in Ukrainian).

Sievidova, I., \& Leshchenko, L. (2020). Analiz efektyvnosti riznykh kanaliv realizatsii produktsii silskohospodarskykh pidpryiemstv. Halytskyi ekonomichnyi visnyk, 65(4), 60-67. doi: 10.33108/galicianvisnyk_tntu2020. 04.060 (in Ukrainian).

Ulianchenko, O. V., \& Prozorova, N. V. (2016). Osoblyvosti orhanizatsii vyrobnychykh posluh $\mathrm{u}$ silskomu hospodarstvi. Visnyk KhNAU im. V.V. Dokuchaieva. Seriia "Ekonomichni nauky", 2, 292300. URL: http://nbuv.gov.ua/UJRN/Vkhnau_ekon_ 2016_2_34 (in Ukrainian).

Vyslobodska, H. P. (2016). Efektyvnist diialnosti silskohospodarskykh pidpryiemstv na rynku vyrob-nychykh posluh. Innovatsiina ekonomika, 5-6, 92-96. URL: http://nbuv.gov.ua/UJRN/inek_2016_5-6_18 (in Ukrainian).

Vyslobodska, H. P. (2016). Stan rynku vyrobnychykh silskohospodarskykh posluh Lvivskoi oblasti. Ahrosvit, 11, 57-62 URL: http://www.agrosvit.info/ pdf/11_2016/12.pdf (in Ukrainian). 